\title{
Fluorine F 18 DCFBC
}

National Cancer Institute

\section{Source}

National Cancer Institute. Fluorine F18 DCFBC. NCI Thesaurus. Code C96234.

A radioconjug ate containing a low molecular weight tracer, DCFBC, specific for prostatespecific membrane antigen (PSMA) and labeled with the positron-emitting isotope fluorine $\mathrm{F} 18$ with potential prostate tumor imaging upon positron emission tomography (PET). Upon administration, the DCFBC moiety of fluorine F 18 DCFBC specifically targets and binds to the tumor associated antigen PSMA, thereby allowing the visualization of tumor cells expressing PSMA upon PET. PSMA is a transmembrane glycoprotein highly expressed on malignant prostate epithelial cells and vascular endothelial cells of various solid tumors. 